\title{
Testing Sectoral Herding in the Jordanian Stock Market
}

\author{
Mohammad K. Elshqirat ${ }^{1}$ \\ ${ }^{1}$ School of Management, Walden University, Minnesota, U.S.A \\ Correspondence: Mohammad K. Elshqirat, Amman, Jordan.
}

Received: June 17, 2019

Accepted: July 11, 2019

Online Published: July 22, 2019

doi:10.5539/ibr.v12n8p88

URL: https://doi.org/10.5539/ibr.v12n8p88

\begin{abstract}
The main purposes of this quantitative study were to examine the existence of herding behavior among investors in Amman stock exchange (ASE) at market and sector level in addition to testing the behavior during the market rising and falling and examining whether the behavior existence is different before and after the global financial crisis of 2008. The theoretical base of the study was the behavioral finance which assumes that investors are not completely rational and they may follow others when taking investment decisions. The main enquires of the study were about the existence of herding in the Jordanian market, whether it's affected by conditions of market rising and falling, and whether it's affected by the financial crisis. A quantitative design was employed to achieve the purposes of this study which covers the period 2000 - 2018. Data were obtained from ASE website and analyzed using ordinary least squares method. The results indicated that herding is absent in the Jordanian market if tested at market level while it exists in services and industrial sectors if tested at sectors level. The financial crisis did not affect the presence of herding at market level while it did affect the behavior in services and industrial sectors. Moreover, the results revealed that market condition of rising and falling affected herding at market level but not at sectors level. It is also concluded that the global financial crisis changed the presence of herding behavior during conditions of rising and falling in market and in each sector.
\end{abstract}

Keywords: Amman stock exchange, behavioral finance, financial crisis, herding, market falling, market rising, sectoral herding

\section{Introduction}

In the traditional finance, it's assumed that markets are efficient and investors are rational but in behavioral finance, markets are not efficient and investors are normal people who may be affected by cognitive problems (Statman, 2014); these cognitive problems include over and under confidence, over-reaction, cognitive bias, and herding (Shafi, 2014). The problem is that herding behavior may increase volatility and affect the stability and efficiency of financial markets (Shusha \& Touny, 2016). The specific problem is that most of studies about herding were conducted at the market level ignoring the behavior at sector level which may lead to incorrect conclusions about its presence (BenSaïda, 2017). If herding exists, investors may invest in mispriced stocks (Filip, Pochea \& Pece, 2015) because the price does not reflect the fundamental value of the stock but reflect a value derived from the high volume of sales and purchases triggered by herding. Based on this, it's important for investors to know if herding exists in the market to consider that in their investment decisions and to exploit the profitable opportunities that may be caused by the behavior (Demirer \& Zhang, 2018). Herd behavior in financial markets was studied in many areas including its existence (Curto, Falcão \& Braga, 2017; Hammami \& Boujelbene, 2015; Mertzanis \& Allam, 2018), the differences between individual and institutional herding (Hsieh, 2013; Li, Rhee, \& Wang, 2017; Trenca, Pece \& Mihut, 2015), the causes of herding (Chang \& Su, 2017; Fang, Lu, Yau \& Lee, 2017; Shusha \& Touny, 2016), and the impact of herding on investment decisions (Akbar, Salman, Mughal, Mehmood \& Makarevic, 2016; Bakar \& Yi, 2016; Kengatharan \& Kengatharan, 2014).

In Jordan, however, few studies were conducted to test the presence of herding (Al-Shboul, 2012a; Obaidat, 2016; Ramadan, 2015), the causes of herding (Nasarudin, Noordin, Law \& Yahya, 2017), and the impact of herding (Alrabadi, Al-Abdallah \& Aljarayesh, 2018, Areiqat, Abu-Rumman, Al-Alani \& Alhorani, 2019). The main purposes of this study were to test the presence of herding and examine the effect of market conditions of rising and falling and the global financial crisis on the behavior at market-level and sector-level. To achieve these objectives, four pairs of hypotheses were developed. In the first pair, it's assumed that investors in the Jordanian stock market and in each sector herd when taking investment decisions while the second pair was related to determine the effect of global financial crisis of 2008 on the presence of herding behavior in the market and in 
each sector separately. The third pair of hypotheses was formulated to examine the behavior during market and sector rising and falling. The last two hypotheses were developed to test the difference in the effect of market conditions of rising and falling on the presence of herding behavior before and after the financial crisis of 2008 . These hypotheses were tested using a quantitative design following most studies in the literature. Testing the presence of herding behavior in Amman stock exchange may help in explaining why the prices of stocks cannot be predicted using the traditional pricing models and may provide investors with more information about how the stocks are being priced in the Jordanian market.

\section{Literature Review}

\subsection{Behavioral Finance}

Behavioral finance is the field of study that focuses on the impact of psychological factors on the behavior of investors and how it leads them to take irrational investment decisions (Shafi, 2014). In addition, behavioral finance replaces many aspects of standard finance with new behavioral-based aspects; for example, it replaces the mean-variance portfolio theory in the traditional finance with the behavioral portfolio theory, replaces the term rational people with normal people, and replaces the financial assets pricing models with behavioral asset pricing models (Statman, 2014). Some market results may be different from that anticipated by the traditional finance theories including the efficient market hypothesis, these results can be explained by the behavioral finance through the study of behavioral biases affecting the investors' decisions (Baker \& Ricciardi, 2015). Based on this, behavioral finance provides explanations for many inefficiencies and anomalies in the financial markets that cannot be explained by the theories of traditional finance.

Examples of behavioral bias that may affect the investment decisions of individuals include: overconfidence, disposition effect, herding, home bias (Kumar \& Goyal, 2015), and representativeness bias (Alrabadi et al., 2018). Overconfidence bias refers to the situation when the investor relies on the subjective judgment more than the objective accuracy (Im \& Oh, 2016); this bias leads people to think that their estimates are more accurate than they really are (Forbes, 2005). Theoretically, rational investor keeps the winning stocks and sells losing stocks (Dharma \& Koesrindartoto, 2018), the cognitive bias of disposition occurred when investors do the opposite by selling winning stocks too early and holding on losing stocks too long (Shefrin \& Statman, 1985). Home bias means that investors prefer to hold portfolios that include a high percentage of domestic stocks rather than international stocks (Mishra \& Daly, 2006). Representativeness bias means that investors select stocks based on its current performance assuming that it will achieve the same returns it achieved recently (Jain, Jain \& Jain, 2015). The main subject of this study is the herding behavior which occurs when the investor takes the same decision of the majority of investors without utilizing her or his knowledge and experience (Qasim, Hussain, Mehboob \& Arshad, 2019).

\subsection{Herding Behavior}

Herding behavior represents one of the cognitive biases that may be exhibited by investors when taking investment decisions. Herding behavior among investors can be defined as the behavior of copying other investors (the herd) and imitating their investment decisions (Bakar \& Yi, 2016). Because the decision of the herd is wrong in the majority of cases, herding behavior leads to increase the volatility of prices in the financial markets (Bakar \& Yi, 2016). In addition, herding behavior affects assets prices and take it away from its intrinsic values estimated using the traditional asset pricing models which may lead to price bubbles and unanticipated crashes (Cakan \& Balagyozyan, 2016). From its definition, herding means that many investors are selling and buying the same stock at the same time without considering its risk and related information; this may cause volatility to increase and stocks' prices to go beyond its fundamental value pushing the market to become inefficient.

As reported by Kumar and Goyal (2015), the majority of studies concerning the behavioral biases among investors were conducted in the United States and other developed countries with a few studies conducted in the developing countries. Behavioral finance is important in emerging markets because the traditional asset pricing models are invalid in some of these markets including the capital asset pricing model (Alqisie \& Alqurran, 2016; Chaudhary, 2017; Elshqirat \& Sharifazdeh, 2018; Obrimah, Alabi \& Ugo-Harry, 2015; Soumaré, Aménounvé, Diop, Méité \& N'sougan, 2013) and the arbitrage pricing theory (Elshqirat, 2019; Gul \& Khan, 2013; Okoro, 2017). Concerning herding behavior, however, the same conclusion about the lack of studies in emerging markets can be noted (Kumar \& Goyal, 2015). Based on this, emerging markets are in need to be studied more to determine whether behavioral biases of investors are affecting the pricing of stocks and the relationship between risk and return. In addition, more studies are needed to examine the difference in herding behavior across different market sectors and conditions and to test the effect of the global financial crisis on the herding behavior 
in emerging markets. This gap in literature represents the cornerstone on which this study was built.

\subsection{Testing Herding Behavior}

According to Demir and Solakoglu (2016), studies that tested herding behavior belong to two groups; one of these groups is concerned with finding an explanation for the behavior of copying the decision of other investors while the other is focused on the cross-sectional standard deviation (CSSD) of dispersion of returns and the cross-sectional absolute deviation (CSAD) of returns. This study belongs to the second group which uses the CSSD to detect the presence of herding among investors. Since its first introduction by Chang, Cheng, and Khorana (2000), CSAD measure was used by many researchers to detect the behavior of herding among investors. Gavriilidis, Kallinterakis, and Tsalavoutas (2016) used CSAD measure to test herding behavior during the month of Ramadan while Filip, Pochea, and Pece (2015) utilized the measure to detect the presence of herding in the countries of central and south-eastern Europe. Other researchers who used CSAD to measure the presence of herding include Ramadan (2015), Demirer and Zhang (2018), Akinsomi, Coskun, and Gupta (2018), and many others. To detect herding behavior, the first step is to calculate CSAD using the following equation (Chiang, Li, Tan \& Nelling, 2013):

$$
\operatorname{CSAD}_{t}=\frac{\sum_{i=1}^{N}\left|R_{i, t}-R_{m, t}\right|}{N}
$$

Where $\mathrm{CSAD}_{t}$ is the measure of stocks returns' dispersion on day $t, \mathrm{R}_{\mathrm{i}, \mathrm{t}}$ is the realized return for stock $i$ on day $t$, $\mathrm{R}_{\mathrm{m}, \mathrm{t}}$ is the average of realized returns of all stocks on day $\mathrm{t}$ (Gavriilidis, Kallinterakis \& Tsalavoutas, 2016), and $\mathrm{N}$ is the total number of stocks on day t. The second step is to run a multiple regression using the following model (Chang, Cheng \& Khorana, 2000):

$$
C S A D_{t}=\alpha+\lambda_{1}\left|R_{m i, t}\right|+\lambda_{2}\left(R_{m i, t}\right)^{2}+\varepsilon_{t}
$$

Where $\operatorname{CSAD}_{t}$ is the returns' dispersion calculated in Equation $1, \mathrm{R}_{\mathrm{mi}, \mathrm{t}}$ is the realized return of market index on day $\mathrm{t}, \varepsilon_{\mathrm{t}}$ is the error term. These two equations were adjusted to test herding in different sectors, different market conditions, and before and after the global financial crisis as explained in the method section of this study. In the traditional pricing models, it's assumed that the relationship between stocks returns' dispersions and market return is linear and positive because each stock has a different beta and thus, its returns change differently when market changes leading to an increase in its dispersion. When investors follow the movement of market (practice herding behavior), the dispersions of stocks' returns will decline if the market return increases and the relationship may become nonlinear (Gavriilidis et al., 2016). Based on this, if herding behavior exists, the parameter $\lambda_{2}$ will have a statistically significant negative value because it indicates a negative nonlinear relationship between CSAD and average market return as discussed by Chang et al. (2000).

\subsection{Evidence of Herding}

Herding behavior was evidenced in many financial markets in both developing and developed countries including the United States and United Kingdom (Galariotis, Rong \& Spyrou, 2015), Australia (Al-Shboul, 2012b), China (Mahmud \& Tiniç, 2018), Germany (Kremer \& Nautz, 2013), Spain (Andreu, Gargallo, Salvador, \& Sarto, 2015), Portugal (Holmes, Kallinterakis \& Ferreira, 2013), Turkey (Akinsomi, Coskun \& Gupta, 2018), Indonesia (Candraningrat, 2018), Mongolia (Erdenetsogt \& Kallinterakis, 2016), Pakistan (Qasim et al., 2019), India (Dutta, Gahan, \& Panda, 2016), Romania (Trenca, Pece \& Mihut, 2015), South Africa (Nasarudin et al., 2017); Kwait \& Qatar (Demir \& Solakoglu, 2016), Saudi Arabia (Rahman, Chowdhury \& Sadique, 2015), and Tunisia (Hammami \& Boujelbene, 2015). These studies reveal that herding is a global phenomenon that drew the attention of many researchers all around the world.

The presence of herding behavior may be misjudged if studied at market level because herding may not affect all sectors in the market but instead, affect those sectors with specific styles and specific investors' attributes (BenSaïda, 2017). Industry effect on herding was evidenced by Litimi, BenSaïda, and Bouraoui (2016) who found that the effect of herding was not the same in all market sectors and by Choi and Sias, (2009) who argued that industry represents an essential variable that affect the herding behavior of investors. In addition, the differences in herding between sectors was evidenced by Cakan and Balagyozyan, (2016) who concluded that herding was different in financial and technology sectors than other sectors and Sharma, Narayan, and Thuraisamy (2015) who found that herding behavior was stronger in industrial and properties sectors. From these studies, it can be argued that herding behavior may not be the same in all market sectors.

Many studies, however, claimed that herding is not constant but it's changing over time as reported by Sharma et al. (2015) and Curto, Falcão, and Braga (2017). In addition, the level of herding behavior was found to be 
changing based on the market conditions of rising and falling (Chiang et al., 2013; Erdenetsogt \& Kallinterakis, 2016; Rahman et al., 2015) and before and during the global financial crisis (Al-Shboul, 2012a; BenSaïda, Jlassi \& Litimi, 2015). In the Jordanian market, where few studies about herding were conducted, the presence of herding was evidenced by Obaidat (2016), Ramadan (2015), and Nasarudin, Noordin, Law, and Yahya (2017) while no evidence of herding was found by Al-Shboul (2012a) in both conditions of market rising and falling. The objectives behind this study were to update the evidence of herding in the Jordanian stock market, to test whether investors exhibit the behavior when the market is rising and when it's falling, and to examine the presence of the behavior before and after the global financial crisis using the cross-sectional absolute deviation (CSAD). Achieving these objectives at sector level in addition to the market level represents the main value this study may add to the literature.

\subsection{Hypotheses}

To achieve the purposes of the study, four pairs of hypotheses were developed. Each pair of hypotheses consists of two parts: the first part is related to the market in general and the second part is related to each sector in the market namely: financial sector, services sector, and industrial sector. The first pair of hypotheses was developed to test the presence of herding behavior in the Jordanian market and sectors. The second pair was developed to test the effect the global financial crisis of 2008 on the existence of herding behavior while the third pair of hypotheses was to determine if the behavior is significant in both conditions of market rising and falling. The last two hypotheses were related to the difference in the effect of market conditions of rising and falling on the presence of herding behavior before and after the financial crisis of 2008. Research hypotheses can be presented as follows:

H1a: Herding behavior exists in the Jordanian market when tested at market level

H1b: Herding Exists in each sector of the market when tested separately

H2a: Presence of herding behavior at market level is different before and after the global financial crisis

$\mathrm{H} 2 \mathrm{~b}$ : Presence of herding behavior in each sector is different before and after the global financial crisis

H3a: Presence of herding behavior at market level is different during times of market rising and falling

$\mathrm{H} 3 \mathrm{~b}$ : Presence of herding behavior at sector level is different during times of sector's index rising and falling

H4a: The effect of the conditions of market rising and falling on the presence of herding at market level is not the same before and after the financial crisis

$\mathrm{H} 4 \mathrm{~b}$ : The effect of the conditions of sector's index rising and falling on the presence of herding at sector level is not the same before and after the financial crisis 


\section{Method}

\subsection{Research Data}

The study included all listed companies in Amman Stock Exchange (ASE) for the period from January 2000 to December 2018. This period was divided into two sub-periods when measuring the effect of the financial crisis: January 1, 2000-December 31, 2007 (before the crisis) and January 1, 2009-December 31, 2018 (after the crisis) considering that the global financial crisis started in 2007 and its effect reached Jordan in 2008. ASE includes three main sectors: financial sector, services sector, and industrial sector; number of companies in each sector as of December 31, 2018 was 98, 46, and 47 respectively with a total of 191 listed companies. ASE free float index was used as a proxy for the market to calculate the daily market returns. Daily closing prices for listed companies and for the ASE free float index were downloaded from the ASE website for the period from January 1, 2000 to December 31, 2018. Study variables were calculated using these data and analyzed using the ordinary least squares method (OLS) following the approach of Chang et al. (2000).

\subsection{Research Design}

This quantitative study was designed to test the presence of herding behavior among investors in the Jordanian stock market at market level and sector level. In addition, the objectives of the study included examining the differences in the behavior before and after the global financial crisis and under the conditions of market rising and falling. Herding was examined by testing the relationship between the dependent variable of cross-sectional absolute deviation (CSAD) and the independent variables of absolute value and squared value of market index return $\left(\mathrm{R}_{\mathrm{mi}, \mathrm{t}}\right)$.

\subsection{Variables Definitions}

Average of realized returns of stocks in the market $\left(\mathrm{R}_{\mathrm{m}, \mathrm{t}}\right)$ : is the average return of all available stocks in the market on day t. this average was calculated using the simple average of returns of all stocks available on each specific day.

Average of realized returns of stocks in the sector $\left(\mathrm{R}_{\mathrm{ms}, \mathrm{t}}\right)$ : this variable is the simple average of stocks' returns available in the sector on day t.

Cross-sectional absolute deviation (CSAD) for the market: is a measure of the dispersion of stocks' returns utilized by Chang et al. (2000) to detect herding behavior among investors. This measure is calculated as follows (Chiang et al., 2013):

$$
\operatorname{CSAD} t=\frac{\sum_{i=1}^{N}\left|R_{i, t}-R_{m, t}\right|}{N}
$$

Where $\operatorname{CSAD}_{t}$ is the measure of stocks' returns' dispersion on day $t, R_{i, t}$ is the realized return for stock $i$ on day $t$, $R_{m, t}$ is the average of realized returns of all stocks on day $t$, , and $N$ is the total number of stocks on day $t$.

Cross-sectional absolute deviation for each sector $\left(\mathrm{CSAD}_{\mathrm{s}}\right)$ : is a measure of the dispersion of stocks returns used to detect herding in each sector of the market. This variable was measured as follows:

$$
C S A D_{s t}=\frac{\sum_{i=1}^{N}\left|R_{i, t}-R_{m s, t}\right|}{N}
$$

Where $\operatorname{CSAD}_{s t}$ is the measure of stocks returns' dispersion in each sector on day $t, R_{i, t}$ is the realized return for stock $i$ on day $t, R_{m s, t}$ is the average of realized returns of all stocks in the sector on day $t$, and $\mathrm{N}$ is the total number of stocks in the sector on day $\mathrm{t}$.

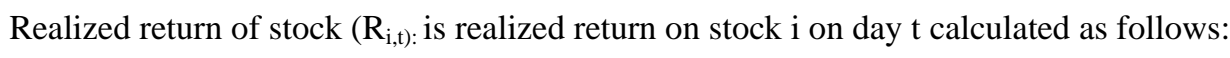

$$
R_{i, t}=\left[\frac{P_{i, t}-P_{i, t-1}}{P_{i, t-1}}\right] * 100
$$

Where $\mathrm{P}_{\mathrm{i}, \mathrm{t}}$ is the closing price of the stock $\mathrm{i}$ on day $\mathrm{t}$ and $\mathrm{P}_{\mathrm{i}, \mathrm{t}-\mathrm{i}}$ is the closing price of that stock at day $\mathrm{t}-1$ or the day before.

Realized return of market index $\left(\mathrm{R}_{\mathrm{mit}, \mathrm{t}}\right)$ : is the return on the market free float index on day $t$. This return was calculated using the following equation:

$$
R_{m i, t}=\left[\frac{P_{m i, t}-P_{m i, t-1}}{P_{m i, t-1}}\right] * 100
$$


Where $\mathrm{P}_{\mathrm{mi}, \mathrm{t}}$ is the closing price of the Amman stock exchange index (ASE) on day $t$ and $\mathrm{P}_{\mathrm{mit}, \mathrm{1}}$ is the closing price of the index on day $\mathrm{t}-1$

Realized return of sector index $\left(\mathrm{R}_{\text {mis,t }}\right)$ : this is the return on the sector index calculated as follows:

$$
R_{m i s, t}=\left[\frac{P_{m i s, t}-P_{m i s, t-1}}{P_{m i s, t-1}}\right] * 100
$$

Where $\mathrm{P}_{\text {mis, }}$ is the closing price of the sector index on day $t$ and $\mathrm{P}_{\text {mis, }-1-1}$ is the closing price of that index on day $\mathrm{t}-1$.

\section{Results}

\subsection{Descriptive Statistics}

Amman stock exchange (ASE) consists of three sectors: financial sector, services sector, and industrial sector. As on December $31^{\text {st }}$, 2018, total number of companies in each sector was 98,46 , and 47 respectively. It can be noted from these numbers that the financial companies represent about $51 \%$ of total listed companies while both services and industrial sectors have the same share of listed companies. Descriptive information about the variables of the study are summarized in Table1.

Table 1. Descriptive Statistics about Variables of: $\mathrm{CSAD}_{\mathrm{T}}, \mathrm{CSAD}_{\mathrm{ST}}$, Absolute Value of Market Index Returns, and Absolute Value of Sectors' Index Returns

\begin{tabular}{|c|c|c|c|c|}
\hline Variable & Mean & $\begin{array}{l}\text { Standard } \\
\text { deviation }\end{array}$ & Min & Max \\
\hline $\mathrm{CSAD}_{\mathrm{t}}$ & 1.217 & 0.500 & 0.000 & 17.345 \\
\hline $\begin{array}{l}\text { CSAD financial } \\
\text { sector }\end{array}$ & 1.183 & 1.029 & 0.000 & 60.218 \\
\hline $\begin{array}{l}\text { CSAD services } \\
\text { sector }\end{array}$ & 1.262 & 0.691 & 0.000 & 16.388 \\
\hline $\begin{array}{l}\text { CSAD industrial } \\
\text { sector }\end{array}$ & 1.179 & 0.794 & 0.000 & 44.937 \\
\hline $\begin{array}{l}\text { Absolute value of } \\
\text { market index returns }\end{array}$ & 0.545 & 0.616 & 0.000 & 4.797 \\
\hline $\begin{array}{l}\text { Absolute value of } \\
\text { financial sector index } \\
\text { returns }\end{array}$ & 0.560 & 0.641 & 0.000 & 5.392 \\
\hline $\begin{array}{l}\text { Absolute value of } \\
\text { services sector index } \\
\text { returns }\end{array}$ & 0.543 & 0.607 & 0.000 & 4.403 \\
\hline $\begin{array}{l}\text { Absolute value of } \\
\text { industrial sector } \\
\text { index returns }\end{array}$ & 0.705 & 0.833 & 0.000 & 20.079 \\
\hline
\end{tabular}

\subsection{Hypotheses Testing}

\subsubsection{Hypothesis One}

Hypothesis one consisted of two parts: the first part was to test the presence of herding in the entire market. This part included testing the following regression model:

$$
C S A D_{t}=\alpha+\lambda_{1}\left|R_{m i, t}\right|+\lambda_{2}\left(R_{m i, t}\right)^{2}+\varepsilon_{t}
$$

Where $\operatorname{CSAD}_{\mathrm{t}}$ is the returns' dispersion calculated in Equation 1 and $\mathrm{R}_{\mathrm{mi}, \mathrm{t}}$ is the realized return of market index on day t. If herding exists among investors, $\lambda_{2}$ will have a negative and significant value. The null hypothesis here was that herding does not exist in the Jordanian market at market level and the alternate hypothesis was that herding does exist in the market at the same level. Based on the results summarized in table 2 and using a significance level of 5\%, the null hypothesis cannot be rejected which means that herding behavior does not exist in the Jordanian market at market level $\lambda_{2}=-0.016, p=.066$ 
Table 2. Regression Analysis Results for Hypothesis One-First Part

\begin{tabular}{lccc}
\hline Details & Value & $t$ statistic & $P$ value \\
\hline$\alpha$ & 0.995 & 92.278 & .000 \\
$\lambda_{1}$ & 0.426 & 17.211 & .000 \\
$\lambda_{2}$ & -0.016 & -1.839 & .066 \\
Adjusted R square & .225 & & \\
\hline
\end{tabular}

The second part of hypothesis one was to test whether herding behavior does exist in each sector of the market when considered separately. This part included testing the following regression model:

$$
C S A D_{s t}=\alpha+\lambda_{1}\left|R_{\text {mis }, t}\right|+\lambda_{2}\left(R_{\text {mis }, t}\right)^{2}+\varepsilon_{t}
$$

Where $\mathrm{CSAD}_{\mathrm{st}}$ is the sectors returns' dispersion calculated in Equation 4and $\mathrm{R}_{\text {mis,t }}$ is the realized return of sector index on day t. the same null and alternate hypotheses for the first part were used for this part. Regression results showed in table 3 indicate that the null hypothesis for services and industrial sectors only can be rejected and thus, herding behavior exists in services sector $\lambda_{2}=-0.034, p=.018$ and industrial sector $\lambda_{2}=-0.013, p<.001$, but not in financial sector $\lambda_{2}=-0.021, p=.248$. To test if the herding coefficients are significantlydifferent between services and industrial sectors, a dummy variable was added to Equation 9 named $\mathrm{DS}_{\mathrm{t}}$ which has a value of 1 for services sector and 0 otherwise. The new model was as follows:

$$
C S A D_{s t}=\alpha+\lambda_{1}\left|R_{\text {mis }, t}\right|+\lambda_{2}\left(R_{\text {mis }, t}\right)^{2}+\lambda_{3}\left(R_{\text {mis }, t}\right)^{2} * D S_{t}+\varepsilon_{t}
$$

The null hypothesis for the model in equation 10 is that $\lambda_{2}$ (services sector) $=\lambda_{2}$ (industrial sector). Regression results indicated that the variable $\left(\mathrm{R}_{\mathrm{mis}, \mathrm{t}}\right)^{2} *$ DSt was significant and thus the null hypothesis that $\lambda_{2}$ (services sector) $=\lambda_{2}$ (industrial sector) can be rejected $t(9312)=8.403, p<.001$ as illustrated in the section of (services-industrial sector) in Table 3. This means that the level of herding behavior is significantly different in services sector than industrial sector.

Table 3. Regression Analysis Results for Hypothesis One-Second Part

\begin{tabular}{lccc}
\hline Details & Value & $t$ statistics & $P$ value \\
\hline Financial sector & & & \\
$\alpha$ & 0.969 & 39.960 & .000 \\
$\lambda_{1}$ & 0.409 & 7.556 & .000 \\
$\lambda_{2}$ & -0.021 & -1.157 & .248 \\
Adjusted R square & .048 & & \\
Services sector & & & \\
$\alpha$ & 1.030 & 63.287 & .000 \\
$\lambda_{1}$ & 0.469 & 11.947 & .000 \\
$\lambda_{2}$ & -0.034 & -2.363 & .018 \\
Adjusted R square & & & \\
Industrial sector & .115 & & .000 \\
$\alpha$ & & 62.166 & .000 \\
$\lambda_{1}$ & 1.013 & 13.710 & .000 \\
$\lambda_{2}$ & 0.256 & -6.268 &
\end{tabular}

Adjusted R square 
$\alpha$

$\lambda_{1}$

$\lambda_{2}$

$\lambda_{3}$

Adjusted R square
1.052

0.258

$-0.014$

0.060
98.447

.000

16.833

.000

$-7.587$

.000

.000

\subsubsection{Hypothesis Two}

This hypothesis was developed to test the effect of the global financial crisis on the presence of herding in the market and in each sector separately. The first part of this hypothesis was to examine the difference in the presence of herding behavior in the market before and after the financial crisis of 2008. For this purpose, data were divided into two groups: before January 1, 2008 (from January 1, 2000 to December 31, 2007) and after 2008 (from January 1, 2009 to December 31, 2018). The following two models were utilized:

$$
\begin{aligned}
& C S A D_{t}^{B}=\alpha+\lambda_{1}^{B}\left|R_{m i, t}^{B}\right|+\lambda_{2}^{B}\left(R_{m i, t}^{B}\right)^{2}+\varepsilon_{t} \\
& C S A D_{t}^{A}=\alpha+\lambda_{1}^{A}\left|R_{m i, t}^{A}\right|+\lambda_{2}^{A}\left(R_{m i, t}^{A}\right)^{2}+\varepsilon_{t}
\end{aligned}
$$

Where $\mathrm{B}$ and $\mathrm{A}$ are used to distinguish the period before the crisis (B) and after the crisis (A).

The null hypothesis for this part was that the presence of herding behavior is the same before and after the crisis at market level while the alternate hypothesis was that the presence of herding is different before and after the crisis. The results for the first model (before crisis) are summarized in table 4 Panel A while the results of the second regression (after the crisis) are shown in Panel B. Based on these results, the null hypothesis cannot be rejected which means that the presence of herding was not different before and after the crisis because it was absent in the period before financial crisis $\lambda_{2}^{B}=-0.026, p=.064$ and after the financial crisis $\lambda_{2}^{A}=0.035, p$ $=.184$.

\begin{tabular}{|c|c|c|c|}
\hline \multicolumn{4}{|c|}{ Panel A: Regression results for the period from 2000-2007(before financial crisis) } \\
\hline Details & Value & $t$ statistics & $P$ value \\
\hline$\alpha$ & 0.871 & 40.434 & .000 \\
\hline$\lambda_{1}^{B}$ & 0.506 & 11.596 & .000 \\
\hline$\lambda_{2}^{B}$ & -0.026 & -1.852 & .064 \\
\hline
\end{tabular}

Table 4. Regression Analysis Results for Hypothesis Two-First Part

Adjusted R square .235

Panel B: Regression results for the period from 2009-2018(after financial crisis)

\begin{tabular}{lccc}
\hline Details & Value & $t$ statistics & $P$ value \\
\hline$\alpha$ & 1.058 & 83.387 & .000 \\
$\lambda_{1}^{A}$ & 0.346 & 7.684 & .000 \\
$\lambda_{2}^{A}$ & 0.035 & 1.329 & .184 \\
Adjusted R square & .163 & & \\
\hline
\end{tabular}


The second part of this hypothesis was about the difference in herding presence before and after the financial crisis in each sector separately. To test this hypothesis the following two models were used for each sector in the market:

$$
\begin{aligned}
& C S A D_{s t}^{B}=\alpha+\lambda_{1}^{B}\left|R_{m i s, t}^{B}\right|+\lambda_{2}^{B}\left(R^{B}{ }_{m i s, t}\right)^{2}+\varepsilon_{t} \\
& C S A D_{s t}^{A}=\alpha+\lambda_{1}^{A}\left|R_{m i s, t}^{A}\right|+\lambda_{2}^{A}\left(R_{m i s, t}^{A}\right)^{2}+\varepsilon_{t}
\end{aligned}
$$

These two models are the same as in Equations 11 and 12 but using the sector's index return $\left(\mathrm{R}_{\text {mis, }, t}\right)$ instead of the market index return $\left(\mathrm{R}_{\mathrm{mi}, t}\right)$ and using of $\mathrm{CSAD}_{\mathrm{st}}$ which was calculated using the sector index. The null and alternate hypotheses for this part were the same used in the first part. The results of regression for equation 13 and 14 are summarized in table 5. Based on these results, the null hypothesis for financial sector cannot be rejected $\left(\lambda_{2}^{B}=-0.022, P=.134, \lambda_{2}^{A}=0.003, P=.977\right)$ which means that the presence of herding behavior in this sector was not affected by the global financial crisis. For services sector, however, investors in this sector exhibited herding before the financial crisis $\lambda_{2}^{B}=-0.069, P=.001$ but not after financial crisis $\lambda_{2}^{A}=0.021, P$ $=.622$. The opposite direction was found in the industrial sector where herding was absent before the global financial crisis $\lambda_{2}^{B}=-0.013, P=.723$ and existing after the financial crisis $\lambda_{2}^{A}=-0.007, P<.001$. These results indicate that the presence of herding behavior in services and industrial sectors was affected by the global financial crisis.

Table 5. Regression Analysis Results for Hypothesis Two-Second Part

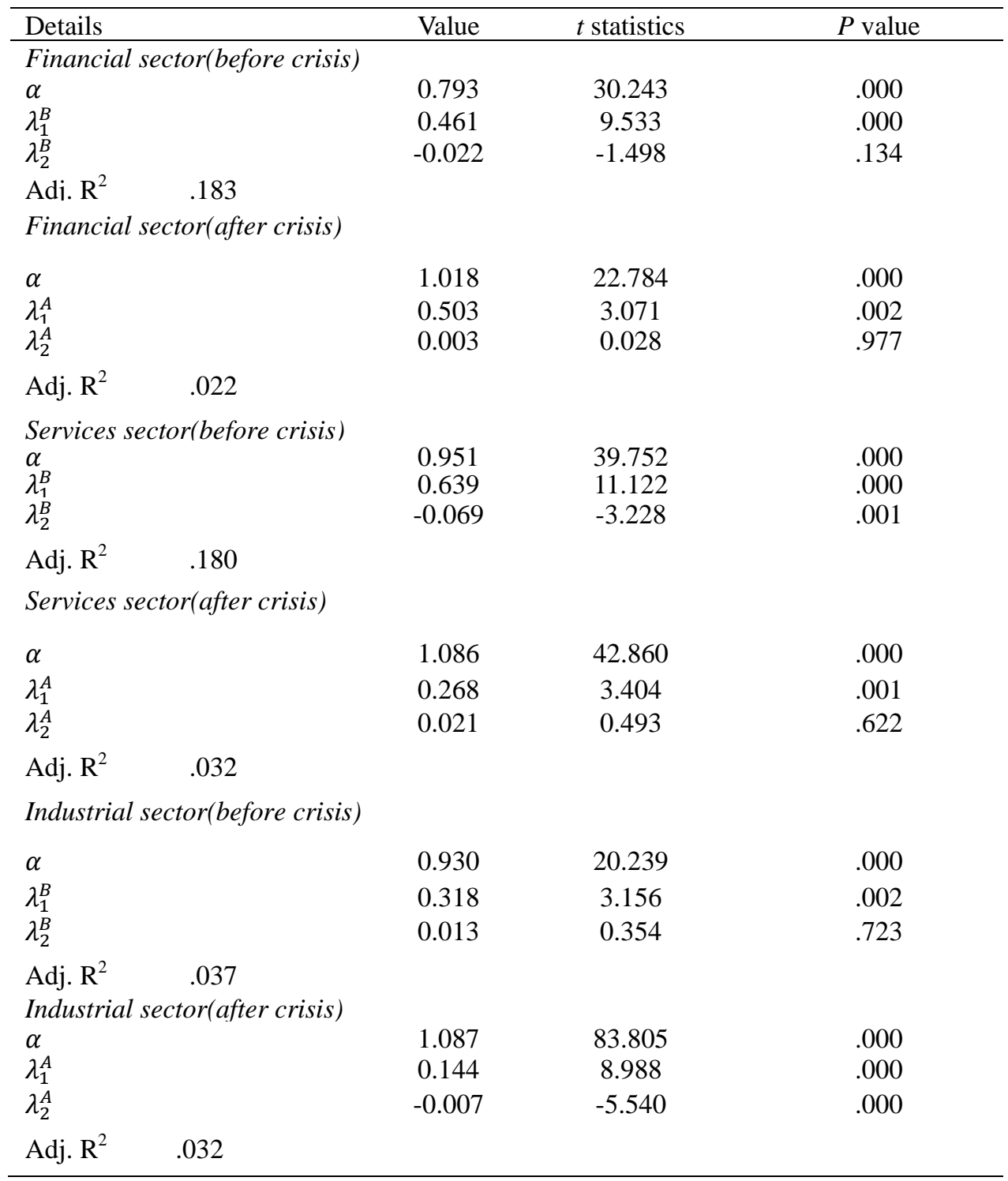




\subsubsection{Hypothesis Three}

This hypothesis was about the difference in herding presence during market rising and falling. The first part of this hypothesis was developed to examine the presence of herding in the market while it's rising (i.e. $R_{\text {mi,t }}>0$ ) and falling (i.e. $\mathrm{R}_{\mathrm{mi}, \mathrm{t}}<0$ ). The following two equations were used to accomplish the objective of this hypothesis:

$$
\begin{aligned}
& C S A D_{t}^{R}=\alpha+\lambda_{1}^{R}\left|R_{m i, t}^{R}\right|+\lambda_{2}^{R}\left(R_{m i, t}^{R}\right)^{2}+\varepsilon_{t} \\
& C S A D_{t}^{F}=\alpha+\lambda_{1}^{F}\left|R_{m i, t}^{F}\right|+\lambda_{2}^{F}\left(R^{F}{ }_{m i, t}\right)^{2}+\varepsilon_{t}
\end{aligned}
$$

Where $\mathrm{R}$ denotes the market rising condition $\left(\mathrm{R}_{\mathrm{mi}, \mathrm{t}}>0\right)$ and $\mathrm{F}$ denotes its falling condition $\left(\mathrm{R}_{\mathrm{mi}, \mathrm{t}}<0\right)$.

The null hypothesis for this part was that the presence of herding is the same during market rising and falling and the alternate hypothesis was that the presence is different. Based on the results summarized in Table 6 , the null hypothesis can be rejected $\lambda_{2}^{R}=0.005, P=.737$ and $\lambda_{2}^{F}=-0.036, P<.001$ which means that herding was absent when the market was rising while it existed when the market was falling. From these results, it can be concluded that the condition of market rising and falling do affect the presence of herding behavior.

\begin{tabular}{|c|c|c|c|}
\hline \multicolumn{4}{|c|}{ Panel A: Regression results when market is rising } \\
\hline Details & Value & $t$ statistics & $P$ value \\
\hline$\alpha$ & 1.044 & 60.619 & .000 \\
\hline$\lambda_{1}^{R}$ & 0.354 & 9.128 & .000 \\
\hline$\lambda_{2}^{R}$ & 0.005 & 0.335 & .737 \\
\hline Adj. $R^{2}$ & \multicolumn{3}{|c|}{ Adj. $R^{2}$} \\
\hline \multicolumn{4}{|c|}{ Panel B: Regression results when market is falling } \\
\hline Details & Value & $t$ statistics & $P$ value \\
\hline$\alpha$ & 0.944 & 72.771 & .000 \\
\hline$\lambda_{1}^{F}$ & 0.503 & 16.581 & .000 \\
\hline$\lambda_{2}^{F}$ & -0.036 & -3.607 & .000 \\
\hline Adj. $R^{2}$ & & & \\
\hline
\end{tabular}

Table 6. Regression Analysis Results for Hypothesis Three-First Part

The second part of this hypothesis was to examine the herding behavior during sector rising and falling $\left(R_{\text {mis, } t}>0\right.$, $R_{\text {mis,t }}<0$ ) instead of the market rising and falling as in the first part. The null and alternate hypotheses for this part were the same of the first part. The following two models were developed to test this part:

$$
\begin{aligned}
& C S A D_{s t}^{R}=\alpha+\lambda_{1}^{R}\left|R_{m i s, t}^{R}\right|+\lambda_{2}^{R}\left(R^{R}{ }_{m i s, t}\right)^{2}+\varepsilon_{t} \\
& C S A D_{s t}^{F}=\alpha+\lambda_{1}^{F}\left|R_{m i s, t}^{F}\right|+\lambda_{2}^{F}\left(R_{m i s, t}^{F}\right)^{2}+\varepsilon_{t}
\end{aligned}
$$

These models are the same in Equations 15 and 16 but with using the return on sector index $\left(\mathrm{R}_{\text {mis,t }}\right)$ instead of the market index return $\left(\mathrm{R}_{\mathrm{mi}, \mathrm{t}}\right)$ and using of $\mathrm{CSAD}_{\mathrm{st}}$ which was calculated using the sector index instead of market index. Regression results summarized in Table 7 revealed that herding was absent in the financial sector during sector rising $\lambda_{2}^{R}=-0.008, P=.475$ and sector falling $\lambda_{2}^{R}=-0.036, P=.295$. In addition, herding was absent in the services sector during sector rising $\lambda_{2}^{R}=-0.029, P=.138$ and during sector falling $\lambda_{2}^{R}=-0.041, P=.051$ while in the industrial sector, herding behavior existed in both sector rising $\lambda_{2}^{R}=-0.011, P<.001$ and sector falling $\lambda_{2}^{R}=$ $-0.015, P=.001$. These results reveal that the presence of herding was not different during sector rising and falling in all sectors. 
Table 7. Regression Analysis Results for Hypothesis Three-Second Part

\begin{tabular}{|c|c|c|c|c|}
\hline Details & & Value & $t$ statistics & $P$ value \\
\hline \multicolumn{5}{|c|}{ Financial sector(sector rising) } \\
\hline$\alpha$ & & 0.982 & 61.423 & .000 \\
\hline$\lambda_{1}^{R}$ & & 0.363 & 10.387 & .000 \\
\hline$\lambda_{2}^{R}$ & & -0.008 & -0.714 & .475 \\
\hline Adi. $\mathrm{R}^{2}$ & .175 & & & \\
\hline \multicolumn{5}{|c|}{ Financial sector(sector falling) } \\
\hline$\alpha$ & & 0.952 & 20.480 & .000 \\
\hline$\lambda_{1}^{F}$ & & 0.466 & 4.404 & .000 \\
\hline$\lambda_{2}^{F}$ & & -0.036 & -1.047 & .295 \\
\hline Adj. $R^{2}$ & .029 & & & \\
\hline \multicolumn{5}{|c|}{ Services sector(sector rising) } \\
\hline $\begin{array}{l}\alpha \\
\lambda_{1}^{R}\end{array}$ & & $\begin{array}{l}1.033 \\
0.446\end{array}$ & $\begin{array}{c}44.223 \\
8.286\end{array}$ & $\begin{array}{l}.000 \\
000\end{array}$ \\
\hline$\lambda_{2}^{R}$ & & -0.029 & -1.484 & .138 \\
\hline Adj. $R^{2}$ & .115 & & & \\
\hline \multicolumn{5}{|c|}{ Services sector(sector falling) } \\
\hline$\alpha$ & & 1.023 & 44.646 & .000 \\
\hline$\lambda_{1}^{F}$ & & 0.501 & 8.681 & .000 \\
\hline$\lambda_{2}^{F}$ & & -0.041 & -1.955 & .051 \\
\hline Adj. $R^{2}$ & .115 & & & \\
\hline \multicolumn{5}{|c|}{ Industrial sector(sector rising) } \\
\hline$\alpha$ & & 1.028 & 73.056 & .000 \\
\hline$\lambda_{1}^{R}$ & & 0.237 & 15.210 & .000 \\
\hline$\lambda_{2}^{R}$ & & -0.011 & -7.628 & .000 \\
\hline Adj. $R^{2}$ & .096 & & & \\
\hline \multicolumn{5}{|c|}{ Industrial sector(sector falling) } \\
\hline$\alpha$ & & 0.998 & 34.473 & .000 \\
\hline$\lambda_{1}^{F}$ & & 0.278 & 7.965 & .000 \\
\hline$\lambda_{2}^{F}$ & & -0.015 & -3.299 & .001 \\
\hline Adj. $R^{2}$ & .029 & & & \\
\hline
\end{tabular}

\subsubsection{Hypothesis Four}

This hypothesis was developed to test whether the effect of market and sector conditions of rising and falling on the presence of herding is different before and after the global financial crisis. The first part was to test this effect at market level while the second part was to test it at sector level. For the first part, the following four models were developed:

$$
\begin{gathered}
C S A D_{t}^{B R}=\alpha_{1}+\lambda_{1}^{B R}\left|R_{m i, t}^{B R}\right|+\lambda_{2}^{B R}\left(R^{B R}{ }_{m i, t}\right)^{2}+\varepsilon_{t} \\
C S A D_{t}^{B F}=\alpha_{2}+\lambda_{1}^{B F}\left|R_{m i, t}^{B F}\right|+\lambda_{2}^{B F}\left(R^{B F}{ }_{m i, t}\right)^{2}+\varepsilon_{t} \\
C S A D_{t}^{A R}=\alpha_{3}+\lambda_{1}^{A R}\left|R_{m i, t}^{A R}\right|+\lambda_{2}^{A R}\left(R^{A R}{ }_{m i, t}\right)^{2}+\varepsilon_{t} \\
C S A D_{t}^{A F}=\alpha_{4}+\lambda_{1}^{A F}\left|R_{m i, t}^{A F}\right|+\lambda_{2}^{A F}\left(R^{A F}{ }_{m i, t}\right)^{2}+\varepsilon_{t}
\end{gathered}
$$

Where $\mathrm{BR}, \mathrm{BF}, \mathrm{AR}$, and $\mathrm{AF}$ denote market rising before financial crisis, market falling before financial crisis, market rising after financial crisis, and market falling after financial crisis respectively. The null hypothesis was that the presence of herding behavior during market rising and falling before the financial crisis is the same as the presence of herding during market rising and falling after the financial crisis; the alternate hypothesis was that the presence during market rising and falling before crisis was different than that after the crisis. From results shown in Table 8, it's concluded that the presence of herding behavior in the market during market rising and falling before the financial crisis was not the same as after it. Before financial crisis, herding was absent 
during market rising $\lambda_{2}^{B R}=-0.005, P=.831$ while it existed during market falling $\lambda_{2}^{B F}=-0.041, P=.004$. After the financial crisis, however, herding was absent during market rising $\lambda_{2}^{A R}=0.010, P=.799$ and during market falling $\lambda_{2}^{A F}=0.050, P=.169$. This means that the presence of herding under the market condition of rising and falling was affected by the global financial crisis.

Table 8. Regression Analysis Results for Hypothesis Four-First Part

\begin{tabular}{lccc}
\hline \multicolumn{4}{l}{ Panel A: Regression results before financial crisis } \\
\hline Details & Value & $t$ statistics & $P$ value \\
\hline$\alpha_{1}$ & 0.931 & 25.915 & .000 \\
$\lambda_{1}^{B R}$ & 0.446 & 6.298 & .000 \\
$\lambda_{2}^{B R}$ & -0.005 & -0.213 & .831 \\
Adj. $\mathrm{R}^{2}$ & .159 & & \\
$\alpha_{2}$ & 0.810 & 37.715 & .000 \\
$\lambda_{1}^{B F}$ & 0.551 & 12.180 & .000 \\
$\lambda_{2}^{B F}$ & -0.041 & -2.869 & .004 \\
& .419 & & \\
Adj. $\mathrm{R}^{2}$ & & & \\
\hline
\end{tabular}

Panel B: Regression results after financial crisis

\begin{tabular}{lccc}
\hline Details & Value & $t$ statistics & $P$ value \\
\hline$\alpha_{3}$ & 1.103 & 62.372 & .000 \\
$\lambda_{1}^{A R}$ & 0.289 & 4.460 & .000 \\
$\lambda_{2}^{A R}$ & 0.010 & 0.255 & .799 \\
Adj. $\mathrm{R}^{2}$ & .110 & & \\
$\alpha_{4}$ & 1.012 & 55.736 & .000 \\
$\lambda_{1}^{A F}$ & 0.415 & 6.646 & .000 \\
$\lambda_{2}^{A F}$ & 0.050 & 1.377 & .169 \\
Adj. $\mathrm{R}^{2}$ & .214 & & \\
\hline
\end{tabular}

The second part of this hypothesis was developed to examine the effect of sector conditions of rising and falling on the presence of herding before and after the global financial crisis. The null and alternate hypotheses were the same as the first part. Four models were developed to test the hypothesis at the sector level:

$$
\begin{aligned}
& C S A D_{s t}^{B R}=\alpha_{1}+\lambda_{1}^{B R}\left|R_{m i s, t}^{B R}\right|+\lambda_{2}^{B R}\left(R_{m i s, t}^{B R}\right)^{2}+\varepsilon_{t} \\
& C S A D_{s t}^{B F}=\alpha_{2}+\lambda_{1}^{B F}\left|R_{m i s, t}^{B F}\right|+\lambda_{2}^{B F}\left(R^{B F}{ }_{m i s, t}\right)^{2}+\varepsilon_{t} \\
& C S A D_{s t}^{A R}=\alpha_{3}+\lambda_{1}^{A R}\left|R_{m i s, t}^{A R}\right|+\lambda_{2}^{A R}\left(R_{m i s, t}^{A R}\right)^{2}+\varepsilon_{t} \\
& C S A D_{s t}^{A F}=\alpha_{4}+\lambda_{1}^{A F}\left|R_{m i s, t}^{A F}\right|+\lambda_{2}^{A F}\left(R_{\text {mis }, t}^{A F}\right)^{2}+\varepsilon_{t}
\end{aligned}
$$

These models are the same as in part one of this hypothesis except that the sector index return $\left(\mathrm{R}_{\text {mis, },}\right)$ is used instead of the market index return $\left(\mathrm{R}_{\mathrm{mi}, \mathrm{t}}\right)$ and that $\mathrm{CSAD}_{\mathrm{st}}$ is used instead of $\mathrm{CSAD}_{\mathrm{t}}$. Based on the results shown in the Appendix, the null hypothesis that herding presence under sector rising and falling is the same before and after the financial crisis can be rejected for the financial sector because herding was absent under sector rising and falling before the crisis $\left(\lambda_{2}^{B R}=-0.033, P=.058, \lambda_{2}^{B F}=-0.004, P=.855\right)$ while after the crisis, herding existed 
under market rising $\left(\lambda_{2}^{A R}=-0.092, P=.032\right)$ and absent under market falling $\left(\lambda_{2}^{A F}=0.087, P=.643\right)$. This means that the financial crisis has affected the relationship between sector condition of rising and falling and herding behavior among investors in this sector. It's worth noting here that herding was absent in the financial sector in the first hypothesis, was absent before and after financial crisis, and was absent under sector rising and falling while it existed after the financial crisis under the condition of sector rising. This means that the global financial crisis affected the behavior of investors in the financial sector pushing them to herd when the sector is rising (if all other variables considered constant).

In the services sector, however, herding behavior before financial crisis was absent when the sector was rising $\left(\lambda_{2}^{B R}=-0.026, P=.388\right)$ and existed when the sector was falling $\left(\lambda_{2}^{B F}=-0.133, P<.001\right)$ while after the crisis, herding was absent under both conditions of rising and falling $\left(\lambda_{2}^{A R}=-0.038, P=.535, \lambda_{2}^{A F}=0.063, P=.278\right)$. Based on this, the null hypothesis can be rejected which means that herding presence under sector rising and falling is not the same before and after the financial crisis. In addition, it can be concluded that the global financial crisis affected the behavior of investors in services sector by convincing them to stop herding when sector is falling (if all other variables considered constant). Finally, investors in the industrial sector did not herd before financial crisis under both conditions of sector rising and falling $\left(\lambda_{2}^{B R}=0.006, P=.815, \lambda_{2}^{B F}=0.021, P\right.$ $=.769)$ while they did herd under both conditions after the financial crisis $\left(\lambda_{2}^{A R}=-0.006, P<.001, \lambda_{2}^{A F}=-0.009\right.$, $P<.001)$. Based on this, the null hypothesis that herding under conditions of sector rising and falling is the same before and after the crisis for the industrial sector can be rejected. In addition, it can be concluded that due to the global financial crisis, investors in the industrial sector changed their behavior and started to herd under both conditions of sector rising and falling.

\section{Discussion}

Based on the study results, it can be concluded that herding is absent in the Jordanian market when studied at market level which is in line with the results reached by Al-Shboul (2012a) and opposite to the results concluded by Obaidat (2016), Ramadan (2015), and Nasarudin et al. (2017). When studied at sectors level, herding was detected in services and industrial sectors but not in financial sector. The presence of herding at sectors level was also concluded by Cakan, and Balagyozyan (2016) who found evidence of herding in all sectors of Turkish market and BenSaïda (2017) who detected herding in 10 out of 12 sectors in the U.S market. In addition, the results of this study revealed that the existence of herding at market level is not different before and after the global financial crisis (it was absent during both periods) which is the same conclusion reached by Al-Shboul (2012a) and opposite to the conclusions of Angela-Maria, Maria, and Miruna (2015) and BenSaïda, Jlassi, and Litimi (2015) who claimed that the global financial crisis affected the herding behavior among investors.

At sectors level, however, herding in the financial sector was absent before and after the financial crisis and thus, the crisis did not affect herding existence in this sector. This conclusion provide support for the conclusion reached by Al-Shboul (2012a) who found no evidence of herding for financial firms in the Jordanian stock market. The case was not the same for other sectors where the global financial crisis affected the presence of herding. Herding existed in services sector before financial crisis but not after the crisis while it was absent in the industrial sector before the crisis and existed after it. When herding was tested during market falling and rising at market level, results indicated that the behavior was absent during market rising and existed during market falling. This conclusion is not in line with the conclusions of Hammami and Boujelbene (2015) who concluded that herding existed in both market conditions of falling and rising and Rahman, Chowdhury, and Sadique (2015) who found that herding is stronger in the condition of market rising. The presence of herding during sectors rising and falling in the sectors was the same indicating that sector condition of rising and falling does not affect the presence of herding despite the conclusions of some researchers like Tabesh, Kelly, and Poulose (2018) who claimed that herding behavior responds differently in each sector for rising and falling conditions. Finally, the results of the study revealed that herding existence during market rising and falling was not the same before the financial crisis and after it when studied at market level indicating that the financial crisis changed the herding behavior of investors during conditions of market rising and falling. The global financial crisis changed the herding behavior during sectors rising and falling in sectors too as it pushed investors in the financial sector to herd during market rising after the crisis. In addition, financial crisis affected herding presence in services sector by stopping the behavior during sector falling. In the industrial sector, investors did not herd before the financial crisis during both conditions of rising and falling but they started herding after the crisis under rising and falling conditions. 
The study included all listed companies and all sectors in Amman stock exchange (ASE) and based on this, its results can be generalized to represent the market and other emerging markets with the same attributes. One limitation for the study is the use of CSAD to measure herding behavior which can be removed by using other herding measures. For the study purposes, ASE allocation of listed companies to each sector was adopted which may add another limitation to the results of study as the companies belong to each sector may not completely represent that sector. The results of this study are important as they add evidence to the claim that studying herding behavior at market level can shade its presence while sectoral analysis may reveal undiscovered patterns of the behavior. Future research may be needed to detect herding at sectors level using different measures and covering different periods. In addition, other studies may be conducted to diagnose the problem of herding among investors in the same sector and to study its effect on their decisions and profitability.

\section{References}

Akbar, M., Salman, A., Mughal, K. S., Mehmood, F., \& Makarevic, N. (2016). Factors affecting the individual decision making: A case study of Islamabad stock exchange. European Journal of Economic Studies, 15(1), 242-258. https://doi.org/10.13187/es.2016.15.242

Akinsomi, O., Coskun, Y., \& Gupta, R. (2018). Analysis of herding in REITs of an emerging market: the case of Turkey. Journal of Real Estate Portfolio Management, 24(1), 65-81. Retrieved from https://aresjournals.org/loi/repm

Alqisie, A., \& Alqurran, T. (2016). Validity of Capital Assets Pricing Model (CAPM)(empirical evidences from Amman Stock Exchange). Journal of Management Research, 8(1), 207-223. https://doi.org/10.5296/jmr.v8i1.8494

Alrabadi, D. W. H., Al-Abdallah, S. Y., \& Aljarayesh, N. I. A. (2018). Behavioral biases and investment performance: does gender matter? Evidence from Amman stock exchange. Jordan Journal of Economic Sciences, 5(1), 77-92. Retrieved from https://journals.ju.edu.jo/JJES

Al-Shboul, M. (2012a). An examination of herd behavior in the Jordanian equity market. International Journal of Economics and Finance, 5(1), 234-249. https://doi.org/10.5539/ijef.v5n1p234

Al-Shboul, M. (2012b). Asymmetric effects and the herd behavior in the Australian equity market. International Journal of Business and Management, 7(7), 121-140. http://doi.org/10.5539/ijbm.v7n7p121

Andreu, L., Gargallo, P., Salvador, M., \& Sarto, J. L. (2015). Bayesian analysis of herding behaviour: an application to Spanish equity mutual funds. Applied Stochastic Models in Business and Industry, 31(6), 745-761. http://doi.org/10.1002/asmb.2087

Angela-Maria, F., Maria, P. A., \& Miruna, P. M. (2015). An empirical investigation of herding behavior in CEE stock markets under the global financial crisis. Procedia Economics and Finance, 25, 354-361. https://doi.org/10.1016/S2212-5671(15)00745-5

Areiqat, A. Y., Abu-Rumman, A., Al-Alani, Y. S., \& Alhorani, A. (2019). Impact of behavioral finance on stock investment decisions applied study on a sample of investors at Amman stock exchange. Academy of Accounting and Financial Studies Journal, 23(2), 1-17. Retrieved from https://www.abacademies.org/journals/academy-of-accounting-and-financial-studies-journal-home.html

Bakar, S., \& Yi, A. N. C. (2016). The impact of psychological factors on investors' decision making in Malaysian stock market: a case of Klang Valley and Pahang. Procedia Economics and Finance, 35, 319-328. http://doi.org/10.1016/S2212-5671(16)00040-X

Baker, H. K., \& Ricciardi, V. (2015). Understanding behavioral aspects of financial planning and investing. Journal of Financial Planning, 28(3), 22-26. Retrieved from https://www.onefpa.org/journal/Pages/default.aspx

BenSaïda, A. (2017). Herding effect on idiosyncratic volatility in US industries. Finance Research Letters, 23, 121-132. https://doi.org/10.1016/j.frl.2017.03.001

BenSaïda, A., Jlassi, M., \& Litimi, H. (2015). Volume-herding interaction in the American market. American Journal of Finance and Accounting, 4(1), 50-69. https://doi.org/10.1504/AJFA.2015.067837

Cakan, E., \& Balagyozyan, A. (2016). Sectoral herding: Evidence from an emerging market. Journal of Accounting and Finance, 16(4), 87-99. Retrieved from http://www.na-businesspress.com/jafopen.html

Candraningrat, I. R. (2018). Analysis of herding behavior in the Indonesian capital stock market. Proceedings of the 1st Aceh Global Conference, Indonesia. https://doi.org/10.2991/agc-18.2019.59 
Chang, C. H., \& Su, F. J. (2017). Stock characteristics and herding formation: evidence from the United States equity market. International Journal of Social, Behavioral, Educational, Economic, Business and Industrial Engineering, 11(11), 2692-2696. Retrieved from https://waset.org/journal/Social

Chang, E. C., Cheng, J. W., \& Khorana, A. (2000). An examination of herd behavior in equity markets: An international perspective. Journal of Banking \& Finance, 24(10), 1651-1679. https://doi.org/10.1016/S0378-4266(99)00096-5

Chaudhary, P. (2017). Testing of CAPM in Indian context. Business Analyst, 37(1), 1-18. Retrieved from http://www.srcc.edu/publications/business-analyst

Chiang, T. C., Li, J., Tan, L., \& Nelling, E. (2013). Dynamic herding behavior in Pacific-Basin markets: Evidence and implications. Multinational Finance Journal, 17(3/4), 165-200. https://doi.org/10.17578/17-3/4-3

Choi, N., \& Sias, R. W. (2009). Institutional industry herding. Journal of Financial Economics, 94(3), 469-491. https://doi.org/10.1016/j.jfineco.2008.12.009

Curto, J. D., Falcão, P. F., \& Braga, A. A. (2017). Herd behaviour and market efficiency: evidence from the Iberian stock exchanges. Journal of Advanced Studies in Finance, 8(2 (16)), 81-93. https://doi.org/10.14505/jasf.v8.2(16).01

Demir, N., \& Solakoglu, M. N. (2016). Herding in middle eastern frontier markets: Are local and global factors important? In P. Andrikopoulos, G. N. Gregoriou, \& V. Kallinterakis (Eds.), Handbook of frontier markets 3-17. Cambridge, MA:Academic Press.

Demirer, R., \& Zhang, H. (2018). Do firm characteristics matter in explaining the herding effect on returns?. Review of Financial Economics, 1-16. https://doi.org/10.1002/rfe.1036

Dharma, W. A., \& Koesrindartoto, D. P. (2018). Reversal on disposition effect: Evidence from Indonesian stock trader behavior. International Journal of Business \& Society, 19(1). 233-244. Retrieved from http://www.ijbs.unimas.my/

Dutta, A., Gahan, P., \& Panda, S. K. (2016). Evidences of herding behaviour in the Indian stock market. Vilakshan: The XIMB Journal of Management, 13(2), 23-40. Retrieved from https://www.xub.edu.in/XUB-JOURNALS/xub-journals-Vilakshan.html

Elshqirat, M. (2019). An empirical examination of the Arbitrage Pricing Theory: Evidence from Jordan. Journal of Studies in Social Sciences, 18(2), 46-67. Retrieved from https://www.infinitypress.info/index.php/jsss/article/viewFile/1832/714

Elshqirat, M., \& Sharifazdeh, M. (2018). Testing a multi-factor capital asset pricing model in the Jordanian stock market. International Business Research, 11(9), 13-22. https://doi.org/10.5539/ibr.v11n9p13

Erdenetsogt, A., \& Kallinterakis, V. (2016). Investors' herding in frontier markets: Evidence from Mongolia. In P. Andrikopoulos, G. N. Gregoriou, \& V. Kallinterakis (Eds.), Handbook of Frontier Markets, 233-249. https://doi.org/10.1016/B978-0-12-803776-8.00012-4

Fang, H., Lu, Y. C., Yau, H. Y., \& Lee, Y. H. (2017). Causes and impacts of foreign and domestic institutional investors' herding in the Taiwan stock market. Emerging Markets Finance and Trade, 53(4), 727-745. https://doi.org/10.1080/1540496X.2015.1103126

Filip, A., Pochea, M., \& Pece, A. (2015). The herding behaviour of investors in the CEE stocks markets. Procedia Economics and Finance, 32, 307-315. https://doi.org/10.1016/s2212-5671(15)01397-0

Forbes, D. P. (2005). Are some entrepreneurs more overconfident than others?. Journal of business venturing, 20(5), 623-640. https://doi.org/10.1016/j.jbusvent.2004.05.001

Galariotis, E. C., Rong, W., \& Spyrou, S. I. (2015). Herding on fundamental information: A comparative study. Journal of Banking \& Finance, 50, 589-598. https://doi.org/10.1016/j.jbankfin.2014.03.014

Gavriilidis, K., Kallinterakis, V., \& Tsalavoutas, I. (2016). Investor mood, herding and the Ramadan effect. Journal of Economic Behavior \& Organization, 132, 23-38. https://doi.org/10.1016/j.jebo.2015.09.018

Gul, A., \& Khan, N. (2013). An application of arbitrage pricing theory on KSE-100 index; a study from Pakistan (2000-2005). IOSR Journal of Business and Management (IOSR-JBM), 7(6), 78-84. https://doi.org/10.9790/487x-0767884

Hammami, H., \& Boujelbene, Y. (2015). Investor herding behavior and its effect on stock market boom-bust 
cycles. IUP Journal of Applied Finance, 21(1), 38-53. Retrieved from

https://iupindia.in/Applied_Finance.asp

Holmes, P., Kallinterakis, V., \& Ferreira, M. L. (2013). Herding in a concentrated market: a question of intent. European Financial Management, 19(3), 497-520. http://doi.org/10.1111/j.1468-036X.2010.00592.x

Hsieh, S. F. (2013). Individual and institutional herding and the impact on stock returns: Evidence from Taiwan stock market. International Review of Financial Analysis, 29, 175-188. https://doi.org/10.1016/j.irfa.2013.01.003

Im, M., \& Oh, J. (2016). Effect of emotion regulation as a de-biasing mechanism on overconfidence in investment behavior. Journal of Financial Services Marketing, 21(3), 209-225. http://doi.org/10.1057/s41264-016-0003-4

Jain, R., Jain, P., \& Jain, C. (2015). Behavioral biases in the decision making of individual investors. IUP Journal of Management Research, 14(3), 7-27. Retrieved from https://www.iupindia.in/Management_Research.asp

Kengatharan, L., \& Kengatharan, N. (2014). The influence of behavioral factors in making investment decisions and performance: Study on investors of Colombo Stock Exchange, Sri Lanka. Asian Journal of Finance \& Accounting, 6(1), 1-23. http://doi.org/10.5296/ajfa.v6i1.4893

Kremer, S., \& Nautz, D. (2013). Short-term Herding of Institutional Traders: New Evidence from the German Stock Market. European Financial Management, 19(4), 730-746. http://doi.org/10.1111/j.1468-036X.2011.00607.x

Kumar, S., \& Goyal, N. (2015). Behavioural biases in investment decision making-a systematic literature review. Qualitative Research in Financial Markets, 7(1), 88-108. http://doi.org/10.1108/QRFM-07-2014-0022

Li, W., Rhee, G., \& Wang, S. S. (2017). Differences in herding: Individual vs. institutional investors. Pacific-Basin Finance Journal, 45, 174-185. https://doi.org/10.1016/j.pacfin.2016.11.005

Litimi, H., BenSaïda, A., \& Bouraoui, O. (2016). Herding and excessive risk in the American stock market: A sectoral analysis. Research in International Business and Finance, 38, 6-21. https://doi.org/10.1016/j.ribaf.2016.03.008

Mahmud, S. F., \& Tiniç, M. (2018). Herding in Chinese stock markets: a nonparametric approach. Empirical Economics, 55(2), 679-711. http://doi.org/10.1007/s00181-017-1281-y

Mertzanis, C., \& Allam, N. (2018). Political instability and herding behaviour: evidence from Egypt's stock market. Journal of Emerging Market Finance, 17(1), 29-59. https://doi.org/10.1177\%2F0972652717748087

Mishra, A., \& Daly, K. (2006). Where do Australians invest?. Australian Economic Review, 39(1), 47-59. https://doi.org/10.1111/j.1467-8462.2006.00395.x

Nasarudin, A. F., Noordin, B. A. A., Law. S. H, Yahya, M. H. (2017). Investigation of herding behaviour in developed and developing countries: Does country governance factor matters? Capital Markets Review, 25(2), 1-14. Retrieved from https://www.mfa.com.my/

Obaidat, A. (2016). The value relevance of accounting information in emerging stock exchange markets" case of Jordan. Research Journal of Finance and Accounting, 7(12), 184-196. Retrived from https://iiste.org/Journals/index.php/RJFA

Obrimah, O. A., Alabi, J., \& Ugo-Harry, B. (2015). How relevant is the capital asset pricing model (CAPM) for tests of market efficiency on the Nigerian stock exchange? African Development Review, 27(3), 262-273. https://doi.org/10.1111/1467-8268.12145

Okoro, C. O. (2017). Macroeconomic factors and stock market performance: evidence from Nigeria. International Journal of Social Sciences and Humanities Review, 7(1). 1-9. Retrieved from http://www.ijsshr.com/journal/index.php/IJSSHR

Qasim, M., Hussain, R., Mehboob, I., \& Arshad, M. (2019). Impact of herding behavior and overconfidence bias on investors' decision-making in Pakistan. Accounting, 5(2), 81-90. Retrieved from http://www.growingscience.com/ac/ac.html

Rahman, M. A., Chowdhury, S. S. H., \& Sadique, M. S. (2015). Herding where retail investors dominate trading: The case of Saudi Arabia. The Quarterly Review of Economics and Finance, 57, 46-60.

https://doi.org/10.1016/j.qref.2015.01.002 
Ramadan, I. Z. (2015). Cross-Sectional absolute deviation approach for testing the herd behavior theory: The case of the ASE index. International Journal of Economics and Finance, 7(3), 188-193. http://doi.org/10.5539/ijef.v7n3p188

Shafi, M. (2014). Determinants influencing individual investor behavior in stock market: a cross country research survey. Arabian Journal of Business and Management Review, 2(1), 60-71. https://doi.org/10.12816/0003720

Sharma, S. S., Narayan, P., \& Thuraisamy, K. (2015). Time-varying herding behavior, global financial crisis, and the Chinese stock market. Review of Pacific Basin Financial Markets and Policies, 18(2), 1-31. https://doi.org/10.1142/S0219091515500095

Shefrin, H., \& Statman, M. (1985). The disposition to sell winners too early and ride losers too long: Theory and evidence. The Journal of finance, 40(3), 777-790. https://doi.org/10.1111/j.1540-6261.1985.tb05002.x

Shusha, A. A., \& Touny, M. A. (2016). The Attitudinal Determinants of Adopting the Herd Behavior: An Applied Study on the Egyptian Exchange. Journal of Finance and Investment Analysis, 5(1), 55-69. Retrieved from https://www.scienpress.com/journal_focus.asp?Main_Id=69

Soumaré, I., Aménounvé, E. K., Diop, O., Méité, D., \& N'sougan, Y. D. (2013). Applying the CAPM and the Fama-French models to the BRVM stock market. Applied Financial Economics, 23(4), 275-285. https://doi.org/10.1080/09603107.2012.718062

Statman, M. (2014). Behavioral finance: Finance with normal people. Borsa Istanbul Review, 14(2), 65-73. https://doi.org/10.1016/j.bir.2014.03.001

Tabesh, H., Kelly, L., \& Poulose, C. (2018). Herding behavior in the Nairobi securities exchange. Journal of Applied Business and Economics, 20(3), 102-112. https://doi.org/10.33423/jabe.v20i3.340

Trenca, I., Pece, A. M., \& Mihut, I. S. (2015). Herd behaviour of Institutional and individual investors in the context of economic governance: Evidence from Romanian stock market. Review of Economic Studies and Research Virgil Madgearu, 8(1), 177-190. Retrieved from https://econ.ubbcluj.ro/rvm/en 


\section{Appendix}

Regression Analysis Results for Hypothesis Four-Second Part

\begin{tabular}{|c|c|c|c|}
\hline \multicolumn{4}{|c|}{ Panel A: Regression results for the financial sector } \\
\hline Details & Value & $t$ statistics & $P$ value \\
\hline \multicolumn{4}{|c|}{ Before financial crisis } \\
\hline$\alpha_{1}$ & 0.791 & 25.107 & .000 \\
\hline$\lambda_{1}^{B R}$ & 0.508 & 8.969 & .000 \\
\hline$\lambda_{2}^{B R}$ & -0.033 & -1.899 & .058 \\
\hline Adj. $R^{2}$ & .233 & & \\
\hline$\alpha_{2}$ & 0.798 & 18.545 & .000 \\
\hline$\lambda_{1}^{B F}$ & 0.391 & 4.756 & .000 \\
\hline$\lambda_{2}^{B F}$ & -0.004 & -0.183 & .855 \\
\hline Adj. $R^{2}$ & .143 & & \\
\hline \multicolumn{4}{|c|}{ After financial crisis } \\
\hline$\alpha_{3}$ & 1.036 & 55.585 & .000 \\
\hline$\lambda_{1}^{A R}$ & 0.481 & 6.896 & .000 \\
\hline$\lambda_{2}^{A R}$ & -0.092 & -2.152 & .032 \\
\hline Adj. $R^{2}$ & .115 & & \\
\hline$\alpha_{4}$ & 0.996 & 11.593 & .000 \\
\hline$\lambda_{1}^{A F}$ & 0.640 & 1.753 & .080 \\
\hline$\lambda_{2}^{A F}$ & 0.087 & 0.464 & .643 \\
\hline $\operatorname{Adj} . R^{2}$ & .020 & & \\
\hline
\end{tabular}

Panel B: Regression results for the services sector

\begin{tabular}{lccc}
\hline Details & Value & $t$ statistics & $P$ value \\
\hline Before financial crisis & & & \\
$\alpha_{1}$ & 0.982 & 27.002 & .000 \\
$\lambda_{1}^{B R}$ & 0.520 & 6.309 & .000 \\
$\lambda_{2}^{B R}$ & -0.026 & -0.864 & .388 \\
Adj. $\mathrm{R}^{2}$ & .157 & & \\
$\alpha_{2}$ & 0.911 & 29.249 & .000 \\
$\lambda_{1}^{B F}$ & 0.806 & 10.044 & .000 \\
$\lambda_{2}^{B F}$ & -0.133 & -4.305 & .000
\end{tabular}

Adj. R ${ }^{2}$

After financial crisis 


$\begin{array}{lccc}\alpha_{3} & 1.067 & 29.706 & .000 \\ \lambda_{1}^{A R} & 0.359 & 3.179 & .002 \\ \lambda_{2}^{A R} & -0.038 & -0.620 & .535\end{array}$

\begin{tabular}{|c|c|c|c|}
\hline Adj. $R^{2}$ & .036 & & \\
\hline$\alpha_{4}$ & 1.099 & 30.537 & .000 \\
\hline$\lambda_{1}^{A F}$ & 0.205 & 1.854 & .064 \\
\hline$\lambda_{2}^{A F}$ & 0.063 & 1.084 & \\
\hline
\end{tabular}

Adj. $R^{2}$

.029

Panel C: Regression results for the industrial sector

Details Value $t$ statistics $P$ value

Before financial crisis

$\begin{array}{llcc}\alpha_{1} & 0.923 & 32.183 & .000 \\ \lambda_{1}^{B R} & 0.338 & 5.543 & .000 \\ \lambda_{2}^{B R} & 0.006 & 0.234 & .815\end{array}$

Adj. $\mathrm{R}^{2}$

$\alpha_{2}$

$\lambda_{1}^{B F}$

$\lambda_{2}^{B F}$

Adj. $\mathbf{R}^{2}$

After financial crisis

$\alpha_{3}$

$\lambda_{1}^{A R}$

$\lambda_{2}^{A R}$

Adj. $\mathrm{R}^{2}$

$\alpha_{4}$

$\lambda_{1}^{A F}$

$\lambda_{2}^{A F}$

Adj. $\mathbf{R}^{2}$
.173

$\begin{array}{lll}0.936 & 10.840 & .000 \\ 0.296 & 1.503 & .133 \\ 0.021 & 0.294 & .769\end{array}$

.019

$\begin{array}{rrr}1.103 & 58.370 & .000 \\ 0.126 & 5.622 & .000 \\ -0.006 & -3.660 & .000\end{array}$

.025

$\begin{array}{lll}1.070 & 59.200 & .000\end{array}$

$\begin{array}{lll}0.166 & 7.079 & .000\end{array}$

$\begin{array}{lll}-0.009 & -4.100 & .000\end{array}$

.038

\section{Copyrights}

Copyright for this article is retained by the author(s), with first publication rights granted to the journal.

This is an open-access article distributed under the terms and conditions of the Creative Commons Attribution license (http://creativecommons.org/licenses/by/4.0/). 